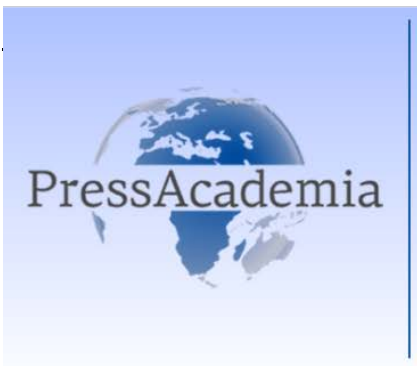

Press Academia Procedía

Global Business Research Congress (GBRC), June 4-5, 2015, Istanbul, Turkey.

\title{
COMPETITIVE STRATEGY IN MARKETING
}

\section{DOI: 10.17261/Pressacademia.2016118135}

\section{Lutfi Saka}

Okan University. lutfi.saka@okan.edu.tr

\begin{abstract}
Key factors in all business are not only to maximize profit in the short term but also It should be created with a successful strategy to provide market recovery. The main topic of this article is to clarify why the market organization gains this important goal. Companies should compete each other to win. They have to effort in order to be the best disciplined market. In other words, they have purposes in terms of having a word about customers and companies' lives and having a leadership role in market chosen and business areas to compete. Competitive pressures are forcing companies increasingly high cost efficiency to accelerate the product development process of continuously developing and monitoring the production process for the win. Companies can take advantage of the rapid progress in information technology and telecommunications fields to create a knowledge economy. Comparing economy to industrial revolution, economy fields have more comprehensive information process and it is benefiting from this advantages. Structures of the organization, replacement of the avoiding the significant reduction in the size of headquarters and in order to recover from the centralization the authority within the hierarchical system are the progress made in this information process. No longer, the companies must promote for needed the information for the decision-making processes to accelerate and to carry out up to lower levels within the company. Because, this motivates to the employees for their reactionary through "aggressive dynamic faster to the act" is authorized to have courage of a personality by taking the risk. At the same time, this causes to the flattening their organizational structures by destroying middle managers their organizational structures.
\end{abstract}

Keywords: Market recovery, productivity, competition, information economy

JEL Codes: A10, A11, D40, E37

\section{PAZARLAMADA REKABET STRATEJILERI}

\section{ÖZET}

Bütün işletmelerde anahtar faktör; sadece kısa vadede karı maksimum düzeye çıkarmaya değil, pazar kazanımı sağlamaya yönelik başarıı bir stratejinin oluşturulmasıdır. Pazar kazanımının niçin bir kurumun tek amacı olmaya yetecek kadar önemli olduğu hususu yazımızın konusunu oluşturmaktadır. Firmalar kazanmak için rekabet ederler. Disipline edilen piyasalarının en iyisi olmak için mücadele vermek zorundadırlar. Bir başka deyişle rekabet etmeyi seçilen pazarlarda ve iş alanlarında önderlik konumlarını tesis etmek ve müşterilerle şirket topluluklarının yaşamlarında söz sahibi olmak gibi amaçlar ön plana alınmaktadır. Kazanmaya yönelik rekabetçi baskılar firmaları giderek daha da yüksek maliyet verimlilikleri izlemeye üretim işlemlerini sürekli olarak geliştirmeye ve ürün geliştirme sürecini hızlandırmaya zorlamaktadır. Şirketler bir bilgi ekonomisi yaratmak üzere bilgi işlem ve telekomünikasyon alanlarında kaydedilen hızlı ilerlemenin avantajlarından yararlanıyorlar. Ekonomi, sanayi devrimine kıyasla daha da geniş kapsamlı olan bir bilgi evrimi süreci yaşamakta olup; bunun avantajlarından faydalanılmaktadır. Organizasyon biçimlerinin, merkez büronun büyüklüğünde önemli küçülmelere ve hiyerarşik sistem dahilindeki yetki ve iradenin merkeziyetçilikten kurtarılmasına yönelik olarak değiştirilmesi, bu bilgi işlem sürecinde kaydedilen ilerlemelerdir. Artık şirketler karar alma sürecini hızlandırmak ve alınan kararların şirket bünyesindeki daha alt kademelere kadar yürütülmesi için gerek duyulan bilgiyi teşvik etmek suretiyle kendi çalışanlarını reaksiyonel "agresif dinamik hızlı hareket edecek" bir kişiliğe ve risk alacak cesarete sahip olacak şekilde yetkilendiriyor ve aynı zamanda, orta kademe yönetici düzeylerini bir bıçak gibi kesip atmak suretiyle aradaki fonksiyon duvarlarını da yıkarak kendi organizasyon yapılarını düzleştiriyorlar.

Anahtar kelimeler: Pazar kazanımı, rekabet, verimlilik ve etkililik, bilgi ekonomisi.

JEL Kodları: A10, A11, D40, E37 


\section{GiRiş}

Pazar sahipleri, kendi sektörlerinde sürekli önder olan yapımcılar veya gelecekte önder olabilmek için sürekli pazarlama faaliyetinde bulunan ve gerektiğinde pazarlama araştırmalarıyla, müşterilerini ve tedarikçilerini birbirine bağlayan yenilikçi ve yaratıcı işlemler yapan firmalardır. Bunlar kurumsallaşmış şirketlerin performansları üzerine ölçüm ve yönetim sistemleri ile geliştirilmiş işlemleri sürdüren keza insanlardaki temel gereksinimleri saptayıp yaratıcı işlemler yapan firmalardır. Pazar sahipleri kendi sektörlerindeki diğer firmalarla rekabet halinde bulunmanın gerekliliğini kavramışlardır. Değişim ve gelişimin sürekliliğine inanmışlardır. Bu nedenle kişi ve kuruluşların evrimci bir yöntemle değişimi anlamaları, hissetmeleri ve inanmaları gerekir. Aksi halde değişim sürecine katılamazlar.

Bütün işletmelerde anahtar faktör; sadece kısa vadede karı maksimum düzeye çıkarmaya değil, pazar kazanımı sağlamaya yönelik başarılı bir stratejinin oluşturulmasındadır.

Pazar kazanımının niçin bir kurumun tek amacı olmaya yetecek kadar önemli olduğu hususu bu yazımızın konusunu oluşturmaktadır. Firmalar kazanmak için rekabet ederler. Disipline edilen piyasalarının en iyisi olmak için mücadele vermek zorundadırlar. Yani rekabet etmeyi seçilen pazarlarda ve iş alanlarında önderlik konumlarını tesis etmek ve müşterilerle şirket topluluklarının yaşamlarında söz sahibi olmak gibi amaçlar ön plana alınmaktadır.

Kendi bünyesindeki pay değerini en üst düzeye çıkarmak bir şirketin birinci derecede öncelikli hedefi olamaz. Firma başarılı ise, tabiatıyla sermaye piyasaları da bu başarıyı dikkate alacaktır. İşte bu nedenledir ki pazar kazanımı aynı zamanda o firmanın uzun vadedeki değerini de maksimum düzeye çıkarır.

Birçok şirket, dünya ekonomisinde meydana gelen ve gerek yerli gerekse uluslararası piyasalarda rekabetin artmasına yol açan temel transformasyonu "değişimi” idrak etmişlerdir.

Kazanmaya yönelik rekabetçi baskılar, firmaları giderek daha da yüksek maliyet verimlilikleri izlemeye, üretim işlemlerini sürekli olarak geliştirmeye ve ürün geliştirme sürecini hızlandırmaya zorlamaktadır.

Şirketler bir bilgi ekonomisi yaratmak üzere bilgi işlem ve telekomünikasyon alanlarında kaydedilen hızlı ilerlemenin avantajlarından yararlanıyorlar.

Ekonomi, sanayi devrimine kıyasla daha da geniş kapsamlı olan bir bilgi evrimi süreci yaşamakta olup; bunun avantajlarından faydalanılmaktadır. Organizasyon biçimlerinin, merkez büronun büyüklüğünde önemli küçülmelere ve hiyerarşik sistem dahilindeki yetki ve iradenin merkeziyetçilikten kurtarılmasına yönelik olarak değiştirilmesi, bu bilgi işlem sürecinde kaydedilen ilerlemelerdir.

Artık şirketler karar alma sürecini hızlandırmak ve alınan kararların şirket bünyesindeki daha alt kademelere kadar yürütülmesi için gerek duyulan bilgiyi teşvik etmek suretiyle kendi çalışanlarını reaksiyonel "agresif dinamik hızlı hareket edecek" bir kişiliğe ve risk alacak cesarete sahip olacak şekilde yetkilendiriyor ve aynı zamanda, orta kademe yönetici düzeylerini bir bıçak gibi kesip atmak suretiyle aradaki fonksiyon duvarlarını da yıkarak kendi organizasyon yapılarını düzleştiriyorlar.

Hâlbuki şirketler işlevlerin çok azını kendi iç bünyelerinde bırakıp, imalattan insan kaynakları yönetimine kadar her şeyin giderek daha da geniş kapsamlı biçimde kaynağında halledilmesi yöntemini benimseyerek, kendi iş yapma şekillerini de değiştiriyorlar. Bunların birçoğu, finansal piyasalardan bilgi işleme kadar ekonomideki hizmetlerin hızı biçimde yükselişini belgeleri ile kanıtlamış durumdadır.

Şirketler artık kendilerini yalnızca ürün imalatçıları veya uzmanlık düzeyinde hizmet sağlayıcıları olarak düşünemez. Aksine, kendilerini küresel rekabetin baskılarına adapte etmenin ve bilgi teknolojisi ile iletişim teknolojisinin giderek birbirine yakınlaşmasıyla yaratılan "bilişim" kavramı ile bunun doğal sonucu olan bilişim ekonomisini hızlandırmanın vasıtalarını geliştirmek zorundadırlar.

"işe başlamak için zaman, hiçbir zaman geç değildir".

Acaba şirketler kendi piyasaları içinde tutarlı olarak nasıl kazanım sağlayabilirler? Bunun gerçekleştirilmesi, şirketlerin kendi işlerini algılayış biçimlerinde köklü değişikliğe gitmelerini de gerekli kılar. Her yeni dönem, yeni ölçütleri de beraberinde getirir. Şirketler, ufukta görünen şiddetli mücadelelere uygun düşecek stratejileri daha 
şimdiden uygulamaya koymak suretiyle, bu bir anda gelip var olan tüm prosedürleri, politikaları kültürü al-aşağı edip yerine yenisini koyma yerine, insanların değişimi anlamaları, hissetmeleri ve inanmalarını, değişim ve gelişimin sürekli olduğunu vurgulayan evrimle geçiren iş atmosferine adapte olmaları gereklidir.

İşte vurgulanmak istenen de bu sırasıyla; giriş, dolaylı hücum ve savunma stratejilerin geliştirilmesi için uygun bir yöntem ortaya koymaktır.

Daha önceki yazılarımda belirttiğim gibi firmalar öncelikle piyasaların yaratııları ve işletmecileri olarak kendi rollerini anlamaları gerekir. Şirketler pazar köprüleri inşa etmek suretiyle, yani müşterilerini ve tedarikçilerini "firmaların harici finansman kaynaklarını" birbirine bağlayan yenilikçi işlemler "ürün kalitesi ve proses verimi/yeniligii" yaratarak kazanırlar. $(1,2)$

İşte bu yaklaşımın kullanılması, birtakım işlemler ve süreçler üzerinde odaklasan ve piyasa ortamını da bir şirketin kendi kontrolü dışındaki bir dış kuvvet olarak gören stratejilerde önemli bir değişimdir.

Pazar kazanımı konusuna ilişkin yeni tip stratejiler lanse edilmektedir. Ancak yeni stratejilerin benimsenmesi misyon ve iş yöntemleri üzerinde yeniden düşünmeyi gerektirir.

İşte bunu yapmalarında şirketlere yardımcı olmak için pazar kazanımında kilit rol oynayan ve MAIN Framework "ana çerçeve" adı verilen bir argümanı kuvvetlendiren ve buna inşa edilen rekabetçi stratejiler oluşturmasını kolaylaştıran dört ayrı pazar giriş stratejisi yani;

1.market making (pazar oluşturma),

2.Arbitration (Arbitraj), "bir piyasada mal ve hizmet satın alıp, sonra da bunları bir başka piyasada yeniden satmak"

3. Intermediation (araclık) "Acente, temsilci, izleyici ve kontrolör simsar, komisyoncu, iletişimci” ve

4. Networking (Ağ oluşturma) performansyonları sunulmaktadır. Şirketler en büyük ekonomik katma değeri sağlayan faaliyetlere odaklanarak başarılı olurlar.

"Ticaret evrensel kurallara bağlıdır. Bunlar zamandan ve zeminden münezzehtir. Ya da yaşanılan topluma ve zamana bağlı değildir. Kârın maksimize edilmesi, bu ișin can alıcı noktasıdır. Ama bunların üstünde mevcut rekabet yasalarının yanı sıra Demokles'in kılıcı gibi olmayı yeğleyen Örgütlü Kamu Vicdanını unutmamak gerekir.

"Değişimin hızlanarak sürdüğü bu dünyada, bu hızdan, başta adresler olmak üzere, tüm iletişim kodları etkilenmektedir. I̧şte bu yüzden kişiler değișmese de kartvizitleri değişir. Karşılıklı kartvizit değişimleri de hiç bitmeden devam eder. Kișisel iletişsim kodları kadar olmasa da, şirketlerin farklı ticari ve sivil toplum kuruluşlarının kendi dinamikleri içinde değişimler yaşadıkları ortadadır. Adresleri değişmese, telefon numaraları değişir; telefon numaraları sabit kalsa, web adreslerinde değişiklikler olabilir. Bütün bu değişimler, tüm prosedürleri (iş süreçlerini), işletme politikalarını, iş kültürünü etkiler ve yerine teknolojik yenilikler ve uygulamaları ikame eder" (3)

Pazar yapımcıları, pazar rekabetini: kendi kontrolleri dışında bir güç olarak görmezler. Onların, önder firmadan anladığı, söz sahibi oldukları pazarları, kurumsal değiştirme (toplumların zaman içindeki gelişimlerini şekillendirdiği) faaliyetleri ile yaratmak, şirketlerinin gelişimini sağlamaktır. Bu firmalar küreselleşen dünyada (standart yapılar ile iş bütünlüğü ve yeknesaklığı sağlama adına) ayakta kalabilmeyi teminen rasyonel yönetimi ilke edinen ve ayrıca hesap verebilmeyi ve şeffaflı̆ıı(denetimi) esas alarak yönetim anlayışı ve faaliyetlerinin sürdürebilirliğini sağlamanın temel prensipleri olması gerektiğini algılamış kuruluşlardır. Aksi takdirde bilgilerin asimetrik olması da gevşekliği artıııı rol oynayabilir (4)

Kişi ya da kuruluş olarak nitelendirebileceğimiz pazar yapımcılarının bir başka türü de sahip olduğu herhangi bir finansal aracın alım-satım fiyatını belirler. Bunlar belirli hisse senetlerinin fiyatlarını sabit tutmak amacıyla, menkul kıymetler borsasında hisse senetlerinin fiyatları düştüğünde alıp, yükseldiğinde satan kişi veya kuruluşlardır. Pazar yapımcılarının bu işlemi yapabilmesi için, hisse senetlerine sahip olması veya hisse senetlerini adına satma yetkisi alması gerekmektedir. piyasa yapımcısı, Yatırımcı ve piyasa arasında bilgi aktarma ve aracılık fonksiyonlarını yerine getiren aracı kurumun likidite sürekliliğini sağlamak ve aşııı fiyat hareketlerini önlemek amacıyla ortaya çıkmıştır. (5)

Piyasa katılımcıları, müşterilerin ticari işlemleri gerçekleştirebilmesi için herhangi bir finansal aracın alım-satım 
fiyatlarını yayımlar. Özellikle kendi müşteri ve üreticilerine güven, kolaylık ve yakınlık sağlarlar. Bu kişiler, karşııkı işbirliği ve alışverişin önemini idrak eden yararlı tedarikçilerdir uygun ürün ve hizmet üretme ve tedarik zinciri yönetiminde ve tedarik işlerini üstlenenler arasındaki ilişkilerin modellenmesi ile ulaşım ve lojistik hizmet veren dağııı ağlarının geliştirilmesini iyi bilir. (6) Ayrıca kendi müşteri ve tedarikçilerine üst seviyede kurum verilerini ve bilgisini devamlı güncelleyerek işleyen ve ayrıştıran bilgi-işlem hizmetleri sunarlar.

Bu çalışmada, yönetim stratejisi, stratejik planlama, vizyon-misyon stratejisi (eylem planı) ya da geleceği kazanmanın yolu: stratejik yönetim ile ilgili çok yeni algılamalar sunulmaya çalışılmaktadır. Yalnızca ürün pazarlarının nasıl kazanılabileceği hususunda yoğunlaşmanın dışında, firmaya, müşteri ile sermaye-hizmet teknoloji ve üretilmiş girdi-tedarikçileri arasında bir köprü olarak bakılmaktadır. Bir şirket bir lojistik strateji yarattığı zaman, lojistik organizasyonun en maliyetli etkinlik olacağı hizmet düzeylerini tanımlıyor demektir. Çünkü tedarik zincirleri sürekli değişmekte ve gelişmektedir. Bir şirket belli ürün hatları, belli ülkeler veya belli müşteriler için birçok lojistik strateji geliştirebilir.

Pazar yapımcıları, rekabet avantajı için uluslararası lojistiği esas alarak, sürekli bilgi-işlem aktarımlarını geliştirerek en etkili pazar köprülerinin kurulumunu başarırlar. Bu sebeple hizmet verdikleri kendi sektörlerinin odak noktası olurlar. Müşteri ve tedarikçiler, pazar sahiplerinin birbiriyle rekabet için giriştikleri faaliyetlerden yararlanırlar. Şirketler, kendi pazarlarını, en üst seviyede sergiledikleri performanslar ile kazanırlar. Sonuç: daha düşük bilgi-işlem, yeni mamul ve hizmet masrafları ve ekonomik büyümedir.

Rekabet stratejisine yönelik standart analizler genellikle dikkatleri ürün-pazar yarışmaları ile sınırlı tutar. Fakat tam tersine, firmanın kendi rekabet stratejisine alternatif pazar köprülerinin yaratıcısı olarak bakması gerektiği görüşünü telkin edilmektedir. Diğer bir deyişle, firma işlemlerini alıcı ve satıcıların karşılıklı etkileşim içinde bulunabilecekleri tüm diğer yollar karşısında rekabet etmek için kullanır. Bazı kimselerin bu yenilikçi stratejilerden kazanılan avantajların rakiplerce taklit edilmesi yüzünden sağlam desteklere istinat etmeyebileceği görüşünü savunacak olmalarına karşın; bu stratejiler yine de suyun başında kalma yöntemleri sağlar.

\section{FIRMANIN RAKIPLERI KIMLERDIR?}

Rekabet, birbirleri ile direkt olarak karşılaşıp işlem yapan alıcı ve satıcılardan kaynaklanabilir, rekabet köhne piyasalardan örgütlü finans piyasalarına kadar değişen, iyi organize olmuş borsalardan kaynaklanabilir. Ve nihayet rekabetin kaynağı, benzer ekonomik işlemler temin eden diğer şirketler de olabilir. Dolayısıyla rekabet, daha iyi bir ürün imal etmekten çok daha fazla anlam ifade eder. Yani rekabet; bir anlamda o ürünün imalat ve dağıtımını yapmak için ihtiyaç duyulan bir dizi ekonomik işle mle rin bütün olarak yürütülmesidir.

Rekabet stratejilerin temelinde de yine Main (Ana) çerçeve yapı bulunmaktadır. Ancak Market Making (Pazar oluşturma), Arbitrage (Arbitraj), Intermediation (Aracılık) ve Networking (Ağ oluşturma) adı verilen bu ana çerçeve yapının önemini iyice kavrayan firmalar yeni rekabet stratejilerini ortaya koyabilirler. Esasen pazar stratejisi, iyi bilinen rekabet stratejilerini çoğaltıp genişleten bir unsurdur. Kurum stratejisinde, hangi pazarlara girilip hangilerinden çıkılacağının belirlenmesi söz konusudur. Bir şirketin pazar stratejileri, o şirketin piyasaya giriş planlarının nasıl uygulamaya konulacağını tayin eder.

Ürün pazarlarında kısa vadeli rekabet taktikleri genelde stratejinin odak noktası olmuştur. Bu taktiklere; fiyatlandırma, pazarlama, satış çabaları, ürün ayrıcalığı ve ürün yenilikleri de dâhildir. Ancak her ne kadar taktik avantajı önemli ise de; yine de uzun vadeli başarının, şirketin tedarikçi ve müşteri piyasalarının her ikisindeki ilişkilerine bakmak suretiyle sağlandığı inancındayım. Pazar kazanımına olanak sağlayan bir strateji, piyasaları yenilikçi yollarla birbirine bağlamayı da gerekli kılar.

Bu konuda yine MAIN çerçeve yapıyı uygulamak suretiyle yeni bir dizi rekabet stratejileri ortaya konulup ve bu stratejileri aşağıdaki kategorilere ayırmak mümkündür.

- Giriş stratejileri (Doğrudan pazar stratejileri)

- Dolaylı stratejiler

- Hücum ve savunma stratejileri 
Piyasa yaratılması ve yönetime ilişkin maliyetler dikkate alındığında, esas itibariyle piyasaya girişin dört şekli olduğunu görmek mümkündür. Bu şekiller göstermektedir ki; firmanın sadece ürün piyasasına bakması onun dar görüşlü olmasından başka b i r şey değildir; çünkü bu takdirde bundan daha karmaşık nitelikteki çok çe şitli saldırı durumlarında yara alabilir.

\section{Porter'ın Rekabet Stratejileri (7)}

\section{Rekabet Stratejileri}

- Porter'ın üç genel rekabet stratejisi..

1) farklılaştırma..

2) toplam maliyet liderliği..

3) odaklanma..

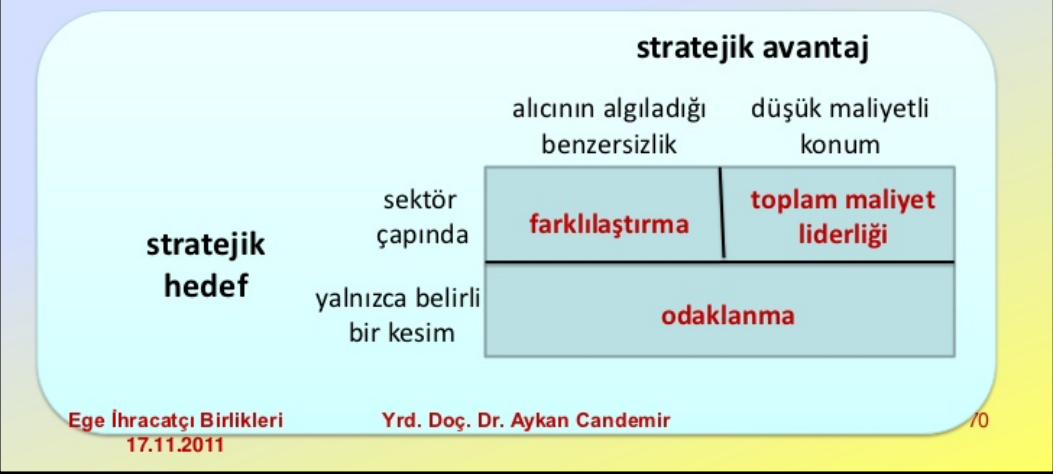

\section{DOĞRUDAN PAZAR STRATEJISI}

Dünyanın ayağınıza gelmesini istiyorsanız, başkalarının yaptığından daha iyisini yapmalısınız. Yenilik hareketleri, ürün dizaynı tabii ki önemlidir. Ancak asıl önemlisi müşteriye direkt ulaşarak, onların nelere ihtiyaç duyduklarını belirlemek ve daha sonra talep edilen ihtiyaçlara verebilecek teknoloji ve ürün dizaynlarını sunabilmektir. Bir firma, ancak sunduğu ürün ve hizmetlerin müşterilerince kendi açılarından birincil kaynak olarak algılanması halinde pazar kazanır. Burada apple güzel bir örnektir. Hem ürün geliştirme adına hemde hizmetlerini doğrudan müşterilerinin ayağına giderek sağlamaktadır. Doğrudan Pazar stratejilerinin esasını hedef Pazar için ekonomik fırsatları belirleyerek bunları yeni yeni yollarla uygulamaya koymaktır. Rakipler, yalnızca benzer ürünleri piyasaya sunan firmalar değildir. Ticari masraflarından tasarruf edebilen firmalar, kendi pazarlarını kazanabilirler. Pazar stratejileri, firmaya Pazar kazanımı ve yönetimi hususlarında avantaj sağlar. Bu geniş çaplı strateji alternatifleri, firmaya Pazar bağlarını geliştirilmesi ve eşsiz bilgilerden istifade edebilme avantajını temin eder.

Pazara girebilmek, stratejik bir sorundur. Bir pazara girmeyi hedefleyen firma yöneticilerinin, aynı zamanda, etkili rekabet manevralarını da beraberinde geliştirmeleri zorunludur. Bir pazara girebilme veya pazarda büyüyebilmeye yönelik temel stratejilerden birisi; üretim, pazarlama, pazar araştırması dâhil, yeni faaliyetler tesis ederek, geri dönülmez yatırımlar yapabilmektir. Firmalar arasında bir fiyat savaşının olması doğaldır. Fiyat savaşı pazarda başarı kazanmak isteyen her firma için günlük mücadelelerinin bir bölümünü oluşturur.

Rekabet piyasasına giriş dört ayrı pazar stratejisinden mevcuttur;

1) Alıcı ile Satıcı Arasına Girmek

- Alıcı ve satıcı arasına girerek, pazar kazanımı ve hizmet sunumlarını direkt olarak sağlamak esasına dayanmaktadır.

2) Konsolidasyon Yolu ile Dağıtıcı ve Tedarikçileri Bir Araya Getirmek

- Farklı sağlayıcılardan tedarik edilen mallar aynı müşteriye tek elden ulaştırılır. 
3) Dağıtıcıların Devreden Çıkarılması

- Dağıtıcı ya da diğer aracıların arasına girerek müşterilere daha da yakınlaşmak ya da toptan tedarikçilerin arasına girerek birincil sağlayıcılar daha da yakınlaşmaktır.

4) Dağıtıcıların Tedarikçi ile Yaptıkları İttifakla Müşteriye Bağlanması

- Kaynağa yakın tedarikçiler ya da kaynaktan uzaktaki dağıtıcılar arasında yapılacak sözleşmeler yolu ile rakiplerle ittifak ederek işbirliğinde bulunmak ve bu sayede ekonomik getiri sağlamaktır.

Bir şirket, piyasadaki işlem maliyetlerini düşürerek rekabet eder. Özetle; araya girme stratejisi izlemek suretiyle firma, alıcı ve satıcılara merkezi alışveriş imkânının sağladığı rahatlık ve düşük maliyetler sunarak, bunlar arasındaki doğrudan işlemlerle rekabet eder. Bir araya getirme stratejisini kullanmak suretiyle şirket, tek duraklı alışverişin rahatığını sunarak, çeşitli kısımlardan oluşan parçalı bir sektörün maliyetlerini düşürür. Bir şirket bypass stratejisini uygulamak suretiyle, müşteri ve tedarikçilere daha yakın olmak için işlem akış yönüne göre kendisinden önce (Upstream) ve sonra (Downstream) gelen firmaları saf dışı bırakıp işlemlerin karmaşıklığını azaltarak işlem maliyetlerini de düşürmüş olur. Burada örnek olarak gıda üreticileri Upstream, müşterilere yakın olan Mc Donald's ve Burger King vs. ise Downstream'e örnek gösterilebilir.

Bağlantı stratejisini kullanmak suretiyle de firma genişleyip veya tedarikçi ya da distribütörlerle şirket evlilikleri gerçekleştirip piyasa işlemlerinin örgütlenmesi olanağını ortadan kaldırır ve bu suretle hemen yanı başındaki işlemlere kıyasla maliyetleri daha etkin biçimde düşürebilir. Bunu müteakip dikkatimizi dolaylı stratejilere, ya da direkt yüz yüze olmanın getireceği yüksek maliyetlere ve düşük getirilere maruz kalmadan pazar kazanımı yollarına çevirmeliyiz.

\section{DOLAYLI STRATEJILER}

\section{Güç Savaşı}

Rakiplerle savaşmadan hiçbir pazarı kazanamazsınız. Sizde önce, diğer rakipler tarafından hiçbir hizmetin ya da daha iyi bir hizmetin götürülmediği pazarlara girerek müşterilere eksik kalmış olanlarda hizmet götürmek temel esastır. Firmalar, ancak ürünü uygun maliyetlerle üretebiliyorlarsa, yüksek ürün performansı sağlayabiliyorlarsa ya da rakiplerinden daha üstün olmalarına yol açacak herhangi bir faaliyette bulunabiliyorlarsa bu savaşta yer almalıdırlar. Bu faaliyetleri uygulayan Dell firmasını buna örnek gösterebiliriz.

\section{Savunmasız (ihmal Edilmiş) Pazarlar}

Mevcudiyetlerini devam ettirebilmek için her firma, daha önce başkaları tarafından yapılmamış şeyler yaparak, müşterilerinin ihtiyaçlarını karşılayarak, memnuniyetlerini kazanmalıdırlar. Savunmasız pazarlar, ticareti kâra dönüştürürler. Franchise emlak sektöründe Re/Max vb. ve devamında Century 21, Era gibi firmalar sektöre girmiştir. Eğer bir firma, yeni bir yolla alıcı ile satıcısını bir araya getirebiliyor ve müşterilerine önceden yapılmamış bir şekilde mal ve hizmet sunabiliyorsa, bu firma pazarda ekonomik bölünmelere yol açacaktır.

\section{Direnme Gücünün Azaltılması Yolu}

Sizden daha güçlü rakiplerinize karşı galip gelmek istiyorsanız direnme gücünün zayıflatılması metodunu kullanmalısınız. Firma maliyetlerinde ya da kâr oranında bir kısıtlamaya giderek ürünü piyasaya daha düşük fiyattan sunarken, piyasadaki yerleşmiş rakipler bu yolla gerçekte bir fiyat rekabetine yol açabileceğinizi algılayamayacakları için firmanızın kendileri açısından herhangi bir tehlike arz etmeyeceğini düşüneceklerdir. Amaç yerleşmiş rakiplere, başlangıçta firma faaliyetlerinizin onlar açısından rekabete yol açacak düzeyde olmadığını hissettirmek olmalıdır. Bu başlığa yine Dell Elektronik firmasını göstererek örnekleme yapabiliriz.

\section{Rakiplerin Şaşırtılması}

Her rekabetin temelinde 'şaşırtmak' vardır. Gerçekte tüm savaşlar 'aldatma' üzerine kurgulanır.Temel felsefe; yakınındayken uzağındaymış gibi, uzağındayken de yakınındaymış gibi hareket edebilme mantığına 
dayanmaktadır.Çünkü yaratılacak şaşkınlık, karşı tarafta, buna yanıt verebilme yeterliliğini azaltacaktır. Firma büyüyüp daha da başarılı oldukça, artık kafa kafaya rekabetten kaçmanın imkânı da kalmaz. Bu noktada bazı piyasalarda işin sırrı, piyasanın hâkimi olan firmanın zayıf noktalarına saldırıp şaşırtma vermek suretiyle, dolaylı yönlendirme ile kazanmaktır. Buna niş pazarların yaratılmasında kozmetik sektörünün büyük önemli markalarının taklitleri ile açılan parfüm satış mağazaları örnek gösterilebilir. Pazar kazanımı çabasında olan firmanın ancak ve ancak kıran kırana etkin bir mücadele sağlayabilecek kuvvet ve kaynaklara sahip olduğu takdirde güçlü durumdaki hâkim firma ile doğrudan rekabet girmesi gerekir. Çünkü piyasaya yeni girmiş olan bir firmanın önceden tam manasıyla hazırlıklı olmadan piyasanın güçlü durumdaki hâkim firması ile doğrudan rekabet içine girmesi, büyük ölçüde başarısızlık riskini de beraberinde getirir.

Pazar kazanımı için bir firma, piyasanın hâkimi olan firmanın göz ardı ettiği ve bu suretle piyasaya yeni giren firmaya deneyim kazanma ve önemli sayılabilecek ölçüde bir müşteri tabanı inşa etme olanağı sağlayacağı piyasaları sürekli izleyerek işe başlamalıdır. Piyasaya yeni giren firmalar önemli ölçüde büyüyebilir ve hatta piyasanın hâkimi konumundaki firmayı - onların radar ekranında kendini göstermeden - devralabilir. Hâkim konumda hiçbir firmanın mevcut olmadığı piyasaları ele geçirmek suretiyle sağlam temeller üzerine bina edilen bir firma daha sonra başka piyasalara girerken artık iyice sıkı bir duruma gelmiş bulunacak ve o piyasaların hâkimi konumunda olan firmalarla doğrudan rekabete hazır olacaktır. Bu rekabet içerisinde Samsung, android teknolojisi ile bunu kanıtlamıştır.

Kendisinden daha kuvvetli bir rakiple at başı rekabet içinde olan şirketlerin kendilerine pahalıya mâl olan çarpışmalardan kaçınmak ve en büyük katma değer sağlayan piyasa kesimlerine hizmet vermek suretiyle kârlarını maksimum düzeye yükselterek kuvvet ekonomisi arayışında olmaları gerekir. Bu prensibin bir uygulaması da savunmasız bir bölgeye (yani rakipler tarafından normalin altında hizmet götürülen herhangi b ir piyasa kesimine) hizmet vermektir. Normalin altında hizmet verilen bu tür bölgeler coğrafi alanlarla sınırlı olmayıp; ihtiyaçları mevcut ürün ve hizmetlerle karşılanmayan veya rakip firmalarla uğraşırlarken aşırı derecede yüksek işlem maliyetlerine maruz kalan müşteri gruplarını da içerir.

Özetleyecek olursak; birisi en düşük dirence maruz bir yol izleyen (yani, yenilikçi işlemler vasıtasıyla piyasalara hizmet veren) ve diğeri de en düşük beklenti çizgisini takip eden (yani, öncelikle çabuk piyasa yanıtı ve yeni ürün ve hizmetler vasıtasıyla karşı tarafa şaşırtma verme yöntemine dayanan) dolaylı strateji olmak üzere, iki tür dolaylı (endirekt) strateji mevcuttur. Şimdi de dolaylı (endirekt) stratejilerden doğrudan (direkt) stratejilere geçerek, bir şirketin başlıca rakipleri ile nasıl at başı rekabet yaptığına bakacağız. Hücuma yönelik (ofansif) stratejiler birtakım avantaj ve zorlukları da beraberinde getirirler ve o nedenle bunlara ancak ve ancak firmanın piyasa ortamına üstün nitelikte organizasyon, teknoloji ve seçkin müşteri - tedarikçi ilişkileri getirmesi halinde teşebbüs edilmesi gerekir. Hücuma yönelik firma stratejileri de yine MAIN adını verdiğimiz ana çerçeve yapıdan kaynaklanır. Bir firmanın piyasayı oluşturan, arbitraj sağlayan, aracılık yapan ve ağ oluşturan taraf olarak rakiplerini saf dışı bırakması zorunludur.

Piyasaya giren veya piyasada faaliyet göstermekte olup kendi pazar paylarını artıran şirketler, APPLE, SONY vb. piyasada belli bir yere gelmiş olan rakiplerle hücuma yönelik (ofansif) stratejiler yardımı ile mücadele eder; piyasada hakim konumda bulunan firmalar ise bu mücadeleye savunmaya yönelik (defansif) stratejiler kullanarak hazırlanmalıdır. Savunma stratejileri, rekabet piyasasına yeni giren firmaya esnek tepki verebilme ve o firmanın mal ve hizmet sunum kapsamının normalin üzerinde genişlemesini önleyebilme yeteneğini içerir. Hücuma ve savunmaya yönelik her iki tür strateji de müşterilere daha düşük fiyat, yenilikçi nitelikte ürün, daha geniş çeşit ve üstün hizmetler sunulmasını gerektirir. Ülker, Eti, Nestle gibi firmalar bu stratejiyi benimseyerek başarılı olmuşlardır. Fakat bunların dışında gerekli olan bir şey daha vardır: Şirketler müşterilerine, daha verimli işlemler şeklinde, daha büyük rahatlık sağlamak için de hazırlıklı olmalıdırlar. Örnek; Kahve Dünyası.

Herkesin bildiği gibi vakit nakittir. Bu yüzden, iktisadi işlemler zaten zaman alıcı olduklarından pahalıya mâl olurlar. Gecikmeler de maliyetleri iki katına çıkarır. Birincisi, tüketicilerin ve satıcıların fırsat maliyetleri vardır; yani bunların zamanlarını vererek yapacakları başka şeyleri vardır. İkincisi, geciktirilen işlemlerin yararları da azalır; çünkü bu durumda söz konusu işlemlerden sağlanacak yarar daha sonra elde edilmiş olur (yani, tüketiciler ve tedarikçiler geleceğe yönelik getirilerinden indirim yapmış olurlar). İşte rekabet stratejisinin temelinde yatan da bu iki maliyettir. 
Bir ürün daha iyi kalitede olsa dahi gecikmeli olarak temin edildiği takdirde müşterinin ihtiyaçlarını karşılaması yönünden çok az rolü olabilir. Bu durumda müşteri; rahatlık, aciliyet ve işlem verimliliği üzerine yüksek bir değer koyar. İşlem maliyetlerinin düşürülmesi ise müşteriler ve tedarikçiler için bir değer yaratır. Yeni pazarlar yaratmak ve mevcut pazarları verimli olarak yönetmek, başarılı ve kazanan bir stratejinin ayrılmaz iki esas parçasıdır.

Özetlersek, "Pazar Kazanımı" ve "Kazanımın Değeri" kazanmaya yönelik rekabet faaliyetini ve piyasa kazanımları suretiyle yaratılan ekonomi değeri amaçlamaktadır. Ayrıca; piyasayı kazanan firmanın o piyasada daha da çok tanınması sebebiyle giderek artan miktarlarda kazanç sağladığını da belirtilebilir. Esasen bu durum piyasada lider konumunda olan tarafın aynı zamanda pazar gücü, düşük risk ve maliyet ekonomisi sağlayabilmesini de mümkün kılmaktadır. En önemlisi, piyasayı kazanan firma borsanın kurumlarını işletmekle birtakım getiriler elde eder. Bu bağlamda, rekabete yönelik alternatif yaklaşımları ve bu gibi fikirlerin değerlendirilmesi gerekir.

\section{PAZAR KÖPRÜLERININ INŞASI}

"Pazar Köprülerinin Inşası" kapsamındaki MAIN Framework (Ana Çerçeve) konusuyla firmaların nasıl katma değer yarattığını, sırasıyla pazar oluşturma, arbitraj, aracılık ve ağ oluşturma konularının kendileri için çok önemli olduğunu algılamışlardır.

Şirketler; fiyatlandırma, borsa koordinasyonu, piyasayı şeffaflaştırma ve mal ve hizmet tahsisi suretiyle piyasa oluştururlar. Bu konuda firmanın pazar oluşturma faaliyetlerinin piyasaları birbirine bağlamaya ne şekilde hizmet ettiğini ve yenilikçi firmaların işlem akış yönüne göre kendilerinden önce ve sonra gelen piyasalar arasındaki yeni bağlantıları keşfetmek suretiyle başarıya ulaştıkları ortaya konulmaktadır. Pazarda faaliyet gösteren Vestel Grubu bu bağlantı ve akışı tespit ederek başarıya ulaşmıştır. Bunu takiben de, katma değer yaratılmasına esas teşkil eden arbitraj faaliyetleri tipleri (Outletler vs.) tarif ediliyor. Şirketler; yatırımcı, servis sağlayıcı ve imalatçılar da dâhil olmak üzere kendi müşterileri ve tedarikçileri arasında aracı sıfatıyla çalışırlar.

$\mathrm{Bu}$ aracılık faaliyetinin piyasa için gerekli bilgi üretim ve teminini içerdiğini de bir gerçektir. Şirketler kendi müşterileri ve tedarikçileri için temsilci, acente, kontrolör, simsar vb. sıfatlarla hareket etmek suretiyle bilgilendirme yönünden ortaya çıkabilecek asimetrik durumları da giderirler.

Son olarak da, şirketlerin gerek organizasyon yapılarını ve gerekse pazar ağlarını genişletmek suretiyle büyüdüklerini göstermekte ve firmanın ölçek, kapsam, faaliyet alanları ve hızı yönünden kendi sınırlarını zorlamasına ilişkin seçenekleri açıklanmaktadır.

Pazar Stratejileri, pazar kazanımı için gerek duyulan stratejilerin temel elemanlarıdır. Firmaların alternatif biçimlerdeki pazar organizasyonlarına karşı nasıl rekabet etmeleri gerektiğini açıklayan dört stratejiyi ana hatlarıyla ortaya konulmaktadır.

Şirket, piyasadaki alıcı ve satıcılar arasına girebilir; 
Şekil 1: Araya Girme Stratejisi

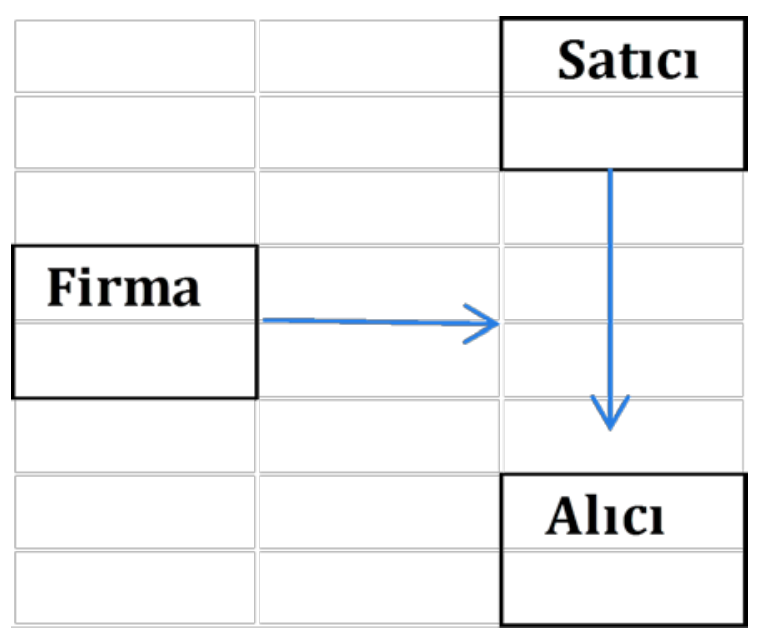

Konsolidasyon yolu ile küçük çaptaki dağıtıcı veya tedarikçi firmaları bir araya getirilebilir. Örneğin; Avm’lerdeki yiyecek içecek yerleri-cafeler.

\section{Şekil 2: Bir Araya Getirme Stratejisi}

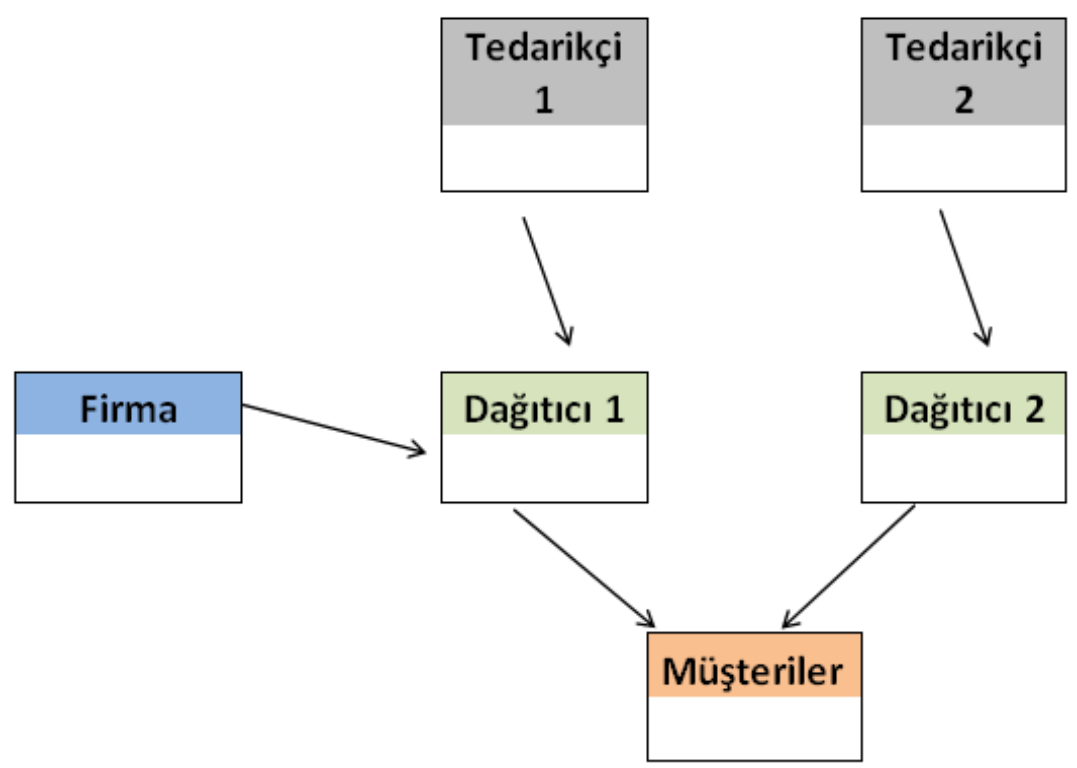

Dağıtıcıları By-Pass yaparak devreden çıkarmak suretiyle (Örn. Apple) müşterilere direkt yaklaşım sağlanabilir; 
Şekil 3: Direkt Yaklaşımda Firmanın Etkinliği

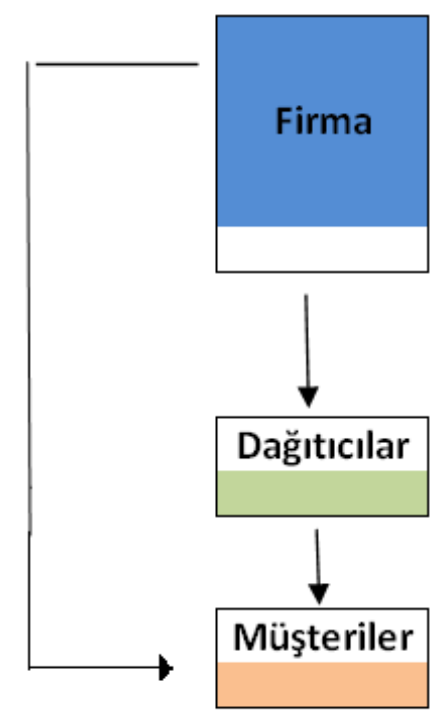

Şekil 4: Bağlama Stratejileri: Dağıtıcı 1 ve 2 ile Tedarikçinin İttifakı

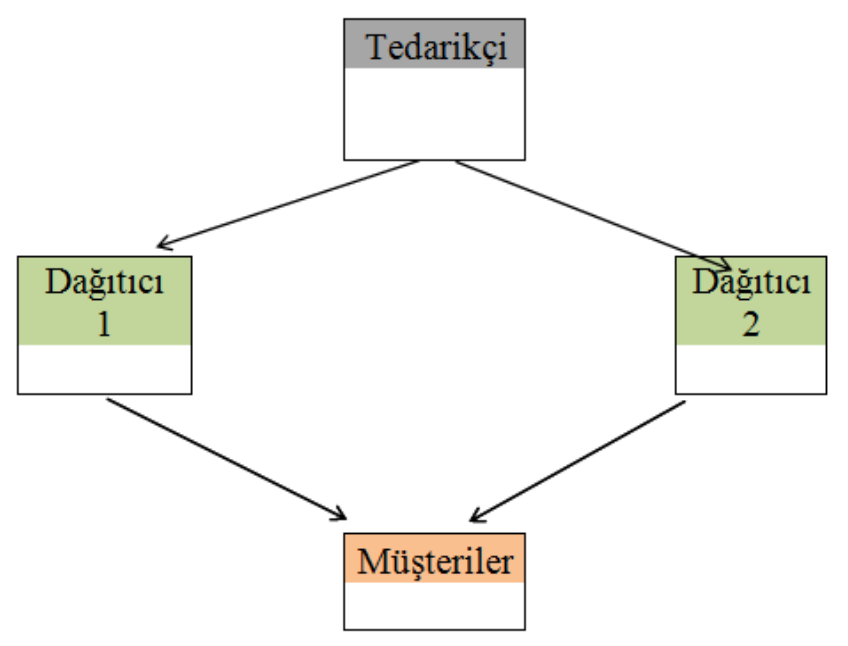




\section{Şekil 5: Bağlama Stratejileri: Tedarikçi 1 ile Dağıtıcının İttifakı}

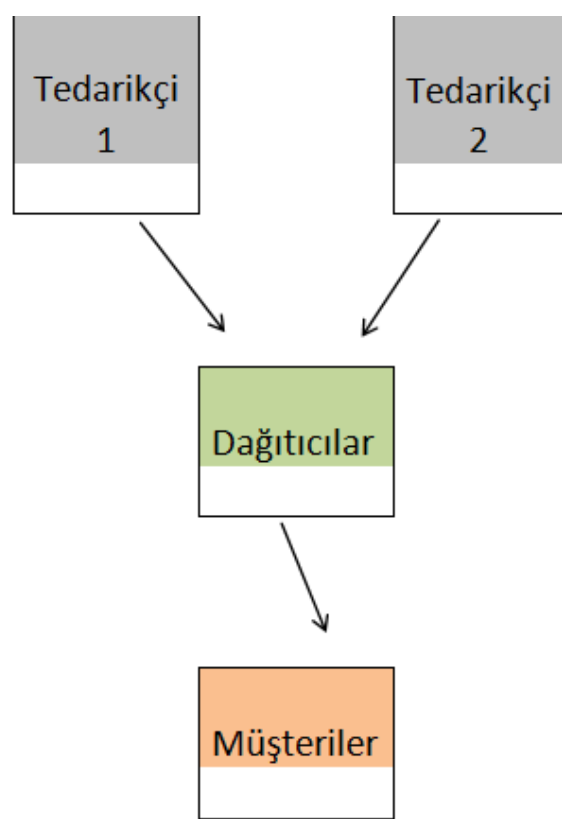

Şirketlerin büyük ve önemli rakipleri tarafından ihmal edilen piyasalara hizmet verebilmek için ne tür ve ne biçimde dolaylı (endirekt) stratejiler izleyebilecekleri ifade edilmektedir. Bir firma yeni piyasalara hizmet götürmek suretiyle, güçlü rakipleri ile direkt olarak yüz yüze gelmeden de büyüyebilir ve gerekli büyüme düzeyine ulaştığı anda doğrudan (direkt) strateji uygulamaya başlayarak, ana rakiplerinin hizmet vermekte olduğu kendisince önemli ve büyük piyasalar için rekabete girebilir. Buna göre MAIN adını verilen ana çerçeve yapıyı esas alan ofansif (hücuma yönelik) ve defansif (savunmaya yönelik) stratejiler değerlendirilebilir

Şirketler, yenilikçi nitelikte pazar oluşturmak suretiyle rakiplerini saf dışı bırakır. Arbitraj avantajını ele geçirmek için de piyasa bilgilerinden en iyi şekilde istifade eder. Üstün nitelikli aracılık hizmetleri sağlar. Ve nihayet, rekabet edici özellikte pazar ağları (Teknosa, Bimeks, Vatan) yaratırlar. Yukarıda belirtildiği üzere pazar köprüleri inşa edilmesine yönelik stratejiler tanıtılmakta ve bu kavramlar pazar kazanımı için gerekli olan rekabet stratejilerinin tasarımına uygulanmasıdır.

\section{SONUÇ}

Televizyondaki yemek programlarında büyük ustanın günün yemek tarifini hazırlama şekli müşterinin dikkatinin nasıl çekileceğine bir örnek teşkil etmektedir. Yemeğin içine konacak tüm malzemeler tezgâhın üzerinde yer alır. Meyveler, sebzeler, baharatlar ve diğerleri hepsi de doğranmış, kesilmiş, küçük kaplar içerisinde yerlerini almışlardır. Şef tarifi verirken malzemeler hakkında şaka yaparak, her birini muhteşem bir yiyecek hazırlamak üzere bir araya getirir. Zaman zaman gösterinin en ilginç bölümünün ekran dışında yer aldığı düşünülür. Tarif defalarca kez test edilip kusursuz hale getirilmiştir.

Pişirme işlemi öncesinde ufak çaplı bir şefler ordusunca malzemeler hazırlanır. Kim bilir belki de en önemlisi, şef ve yardımcılarının en taze malzemeleri satın alarak pazarlamalarını yapmalarıdır. Şef, izleyicilerine bu yemeği hazırlamanın ne kadar da kolay olduğunu anlatır. Ancak evde malzemeleri almak için bile en azından yarım düzine dükkân dolaşmak zorunda kaldığınızda, bu işin o kadar da kolay olmadığını görürsünüz. Çünkü hiçbir şef en zor şeyin pazarlamayı yapmak olduğunu itiraf etmez. Şefin gözlemlediği husus şudur: iyi yemek pişirmek iyi malzemeler - taze, olgun, mevsiminde, bozulmamış ham malzeme - ile başlar. Gecenin menüsünün yaratılmasının altında, karışımların çok kısa sürede, yaratıcılık eşliğinde hazırlanması yatar. Bütün şefler, kendi yemek kitaplarında kendi sağlayıcıları olan, market,çiftlik sahiplerine (muhtelif organik çiftliklerine) teşekkürlerini sunmaktadırlar. 
Yemek yediğiniz mekânın sıcak ve samimi bir ambiyansı olmaksızın, bir yemeği ne kadar en taze malzemeleri kullanarak hazırlarsanız hazırlayın iyi olarak değerlendirilmeyecektir. Müşterilere kendi evlerindeymiş gibi olduklarını hissettirmek şarttır. Mükemmel hizmet sunan büyük restoranların efsanevi şefleri müşteri çekebilmek için her gece farklı bir menü sunmakla beraber pek çok restoranda her gece hep ayın menünün yer aldığını söylemektedir. Çünkü bu tip restoranlar, zaten aynı müşterinin nasıl olsa bir sonraki gece gelmeyeceklerini baştan var saymaktadır. Oysaki kendisi, her gece farklı bir menü hazırlayarak müşterilerin dikkatini çekmeyi başarmaktadır.

Aslında aynı olay şirketler için de geçerlidir. Onlar, ürün ve hizmetlerini üretebilmek için girdilerini birleştirmekten çok daha fazlasını yaparlar, tıpkı şefler gibi. Eğer yalnızca tarife (üretim teknolojisine) ya da pişirme işlemine (faaliyetlere) önem verilirse, büyük resim kolaylıkla kaçırılmış olur. Burada önemli olan şeflerin kendi kullanacakları malzemeleri değişik tedarikçilerden nasıl topladıkları ve müşterilerinin dikkatini çekmeyi nasıl başardıklarıdır.

Firmalar, üretim teknolojisi ve faaliyetlerden daha fazla şeyler yapmaktadırlar. Onlar tedarikçi ve müşterileri arasında bir pazar köprüsü kurarlar. Firmanın sağlayıcıları ile aralarındaki iletişim işlerindeki anahtar noktadır. iş̧ yapabilmek için, sermaye yatıııı, donanımlı çalışanlar ve yüksek kalitedeki tedarikçilerle çalışarak ve en son teknolojik yenilikleri takip ederek sağlamak zorundadırlar.

Şirketlerin, dağıtımcılar ve nihai müşterileri ile olan ilişkileri işin yapılma nedenini oluşturur. Ancak başarııı firmalar, sağlayıııları ve müşterileri arasında bir köprü oluşturabilirler. Sağlayıcılarından aldıkları malları müşterilerine satarak hizmetlerini sunmaktadırlar. Müşteri ve sağlayıcılar arasında tıpkı bir acente gibi aracılık yapmaktadırlar. Son olarak da pazar ağı, güvenilir sağlayıcılar ve memnun olmuş müşteriler arasında oluşur.

Pazar sahipleri, kendi müşteri ve sağlayıcıları için en etkili ticari işlemleri yaratırlar. Ticari işlemlerini en hızlı, en uygun ve düşük fiyattan sunabilmek için rakipleri ile mücadele ederler. Yeterli ticari işlem aktarımı, kaliteli mamul ve hizmet sunumunun esasını oluşturur. Bu tip şirketler müşterilerini uygunluk ve çabuklukları ile kazanırlar. Yeni ticari işlemler geliştirerek pazar paylarını artıııılar.

Firmalar yeni rekabet stratejileriyle alıı ile satıcı arasına girerek, farklı mamul ve malları farkı sağlayıcı ve dağıtımcıları es geçerek tek bir yerden alarak katma değeri büyütür ve müşteri ile sağlayıcıyı en yeni yollarla birbirlerine bağlarlar. Ticari işlemlerin değerini bilen firmalar, müşteri ile sağlayııılarına nasıl hizmet edeceklerini, rakipleriyle olan rekabette nasıl galip geleceklerini bilen firmalardır.

En iyi malzemeleri bir araya getiren büyük şefler gibi, önder firmalar kendi pazarlarını yaratır ve kazanırlar. Firmalar, mevcut pazarlarında büyümek ister. Yeni pazarlara girme gibi, ne şekilde olursa olsun, sürekli olarak bir büyüme çabası içindedirler.

\section{KAYNAKÇA}

Lütfi Saka -Pazar Kazanımı (Tekel Dergisi Kasım- Aralık 1999, Sayı 2, Yıl 18, s.28-3

Lütfi Saka -Kazanmanın Değeri(Tekel Dergisi Haziran-Temmuz 2000,Sayı1,Yıl14,s.62-71)

Mehmet Büyükekşi (Tim Bşk.) Utikad Türkiye Lojistik Kataloğu, 2011 S.16

Yarrow, J. V. (1998). Privatization An Economic Analysis S.9

Daniel F. Spulber - The Market Makers, 1998, S. 6-22,

Douglas M. Lambert - Fundamentals of Logistics Management S. 7

Porter'ın Rekabet Stratejileri 2003- Michael Porter 